\title{
A review of the \\ participation of smallholder \\ farmers in land-based carbon payment schemes
}
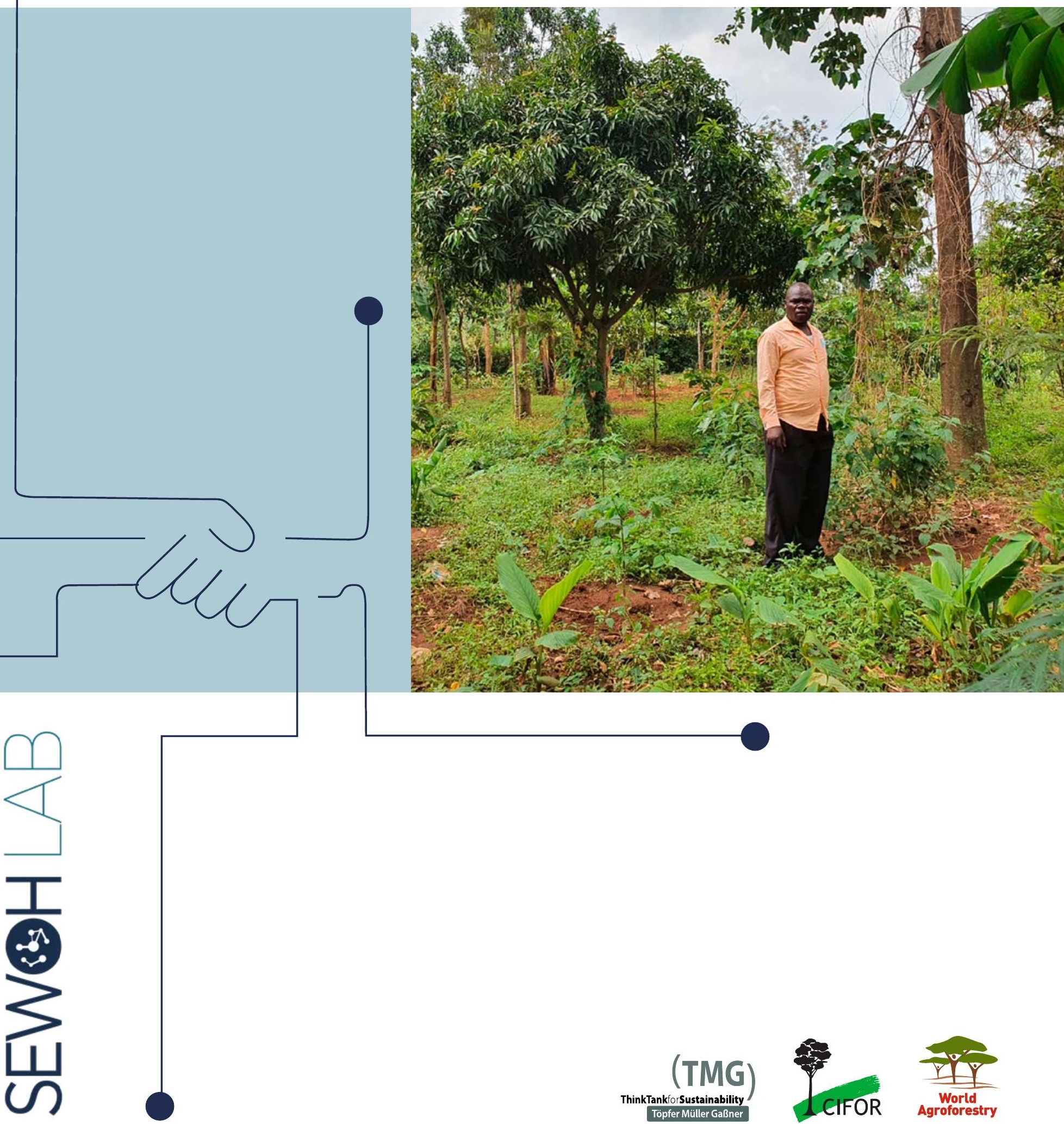


\section{A review of the participation of smallholder farmers in land-based carbon payment schemes}

November 2021

Written by

Yvonne Tamba

Joshua Wafula

Christine Magaju

Ermias Aynekulu

Leigh Winowiecki

World Agroforestry Center
Bruno St-Jacques

Larissa Stiem-Bhatia

Cristina Arias-Navarro

TMG Research gGmbH

\section{Correct citation}

Tamba, Y., Wafula, U., Magaju, C., St-Jacques, B., Stiem-Bhatia L., Arias-Navarro C., Aynekulu, E. and Winowiecki, L., 2021. A Review of the Participation of Smallholder Farmers in Land-based Carbon Payment Schemes. TMG and ICRAF Working Paper. https://doi.org/10.35435/2.2021.4

\section{Acknowledgements}

This research is a joint collaboration between the SEWOH Lab project of TMG Research gGmbH and the World Agroforestry Centre (ICRAF). We acknowledge the support provided by carbon sequestration project leads and experts. Their insights were critical in understanding the complexities surrounding smallholders' participation in carbon payment projects. We also acknowledge CGIAR Research Program on Water, Land and Ecosystems (WLE) and thank our colleagues for their valuable comments on earlier versions of this paper. 


\section{Highlights}

Carbon credit certification standards stipulate local community participation in the project cycle, but evidence and guidelines for effective smallholder participation are not harmonised and vary across standards.

Projects that strengthen social capital can stimulate participation among the marginalized, reduce transaction costs, and promote equity and smallholder agency.

The main incentives for farmers participation in carbon payments schmes are non-monetary, these include: improved yields, access to financial advisory services and credit, investments in local infrastructure and the development of income-generating activities.

Flexibility in project design, including local contract providers and low-cost soil conservation measures, can stimulate participation among marginalized smallholders such as the landless, youth, and women.

Designing and implementing rigorous, participatory, and cost-effective Monitoring Reporting and Verification (MRV) methodologies remains a challenge for many project proponents. 


\section{Abbreviations \& Acronyms}

$\begin{array}{ll}\text { AFOLU } & \text { Agriculture, forestry, and other land use } \\ \text { CBO } & \text { Community-based organisation } \\ \text { CCB } & \text { Climate, Community and Biodiversity } \\ \text { GHG } & \text { Greenhouse gas } \\ \text { IPCC } & \text { International Panel on Climate Change } \\ \text { KACP } & \text { Kenya Agricultural Carbon Project } \\ \text { MRV } & \text { Monitoring, reporting and verification } \\ \text { NDC } & \text { Nationally determined contributions } \\ \text { PES } & \text { Payment for ecosystem services } \\ \text { PRA } & \text { Participatory rural appraisal } \\ \text { REDD+ } & \text { Reducing emissions from deforestation and forest degradation } \\ \text { SLM } & \text { Sustainable land management } \\ \text { SOC } & \text { Soil organic carbon } \\ \text { TGB } & \text { Trees for Global Benefits } \\ \text { TIST } & \text { The International Small Group \& Tree Planting Program }\end{array}$

As part of the 'One World No Hunger' Initiative, financed by the German Federal Ministry for Economic Cooperation and Development, the SEWOH Lab (2020-2024) is an action-oriented research project. Together with partners in Africa and India, it explores, applies, and evaluates the potential of digital innovation in three key areas: urban food systems; sustainable land management and soil organic carbon payments; and gendered access to natural resources.

Looking beyond their climate mitigation potential, our work on Soil Organic Carbon (SOC) is dedicated to identifying the conditions under which such initiatives can contribute to enhance food security and biodiversity. We investigate the challenges involved in operationalising carbon sequestration projects, exploring social and technical innovations that can enhance the benefits of such schemes for smallholder farmers, as well as reducing transaction costs. 


\section{Table of contents}

Executive summary 6

1 Introduction $\quad 7$

$\begin{array}{lll}1.1 & \text { Soil organic carbon as a natural climate solution } & 7\end{array}$

1.2 Carbon markets and carbon credit certification 8

1.3 Participation of farmers and communities in carbon projects 8

2 Materials and methods 9

2.1 Conceptual framework 9

2.2 Research design, and data collection and analysis 10

2.2.1 Selection of land-based carbon offset projects 10

2.2.2 Literature review 11

2.2.3 Interview of key informants 12

3 Results and discussion 13

3.1 Approaches to smallholder participation and engagement 13

3.1.1 Smallholders' participation in project design 13

3.1.2 Smallholders' participation in project monitoring systems $\quad 15$

3.1.3 Carbon payment modalities 16

3.2 Barriers to the participation of farmers in soil carbon projects 17

3.2.1 Land tenure 17

$\begin{array}{ll}3.2 .2 \text { Contracting } & 18\end{array}$

3.3 Enhancing farmers' role, agency, and decision-making in SOC projects 18

3.3.1 Non-monetary incentives for participation 18

3.3.2 The role of local institutions and civil society organisations 19

4 Conclusions and Recommendations 20

$\begin{array}{ll}\text { References } & 21\end{array}$ 


\section{Executive Summary}

There is renewed interest in the engagement of smallholder farmers in carbon markets. This follows in the wake of commitments by governments and companies to reduce or avoid the release of greenhouse gases. It is well known that soil can store large amounts of carbon, and soil stewardship offers a means to harness this potential. However, issues around permanence and scaling in smallholder farmer systems must be addressed if progress is to be made in this area. In this review, we examine the engagement of smallholder farmers in carbon sequestration payment schemes that promote sustainable land management (SLM). Drawing on a review of documents from carbon payment projects, interviews with key informants, and scientific literature, we highlight approaches for smallholder engagement along the project cycle, identify key barriers to participation, and outline options to enhance farmers' agency. In assessing a total of ten projects, we observe considerable variation in participation across the projects.

Project design tools classified as co-decision tools were common, with $60 \%$ of projects reporting the use of individualised land management plans, $30 \%$ the use of participatory rural appraisals (PRAs) and $10 \%$ participatory mapping. However, few projects featured detailed frameworks for the incorporation of community feedback.
The key informant interviews and literature review revealed that low carbon revenues, insecure land tenure, and high transaction costs are the primary barriers to participation, placing disproportionate pressure on marginalised households. Further, designing and implementing rigorous, participatory, and cost-effective monitoring reporting and verification (MRV) methodologies remains a challenge for many project proponents.

We also find that flexible contracts can foster broad participation by including details that are attractive to smallholders such as longer terms, local contract providers and low-cost SLM measures. Projects that strengthen community institutions and social capital can stimulate participation among the marginalised, reduce transaction costs, and promote equity as well as smallholder agency. Engagement with communitybased organisations or other civil society actors can facilitate communication between project proponents and farmers, bolster farmers' bargaining power, and reduce transaction costs during implementation. 


\section{Introduction}

\subsection{Soil organic carbon as a natural climate solution}

The world is facing crises of climate change, land degradation, biodiversity loss, and rising food insecurity. It is estimated that 3.2 billion people are negatively impacted by land degradation (IPBES, 2018) and soil erosion as the most widespread form of land degradation (Vågen and Winowiecki, 2019). Current levels of climate ambition will not suffice to limit global temperature rise to 1.5 degrees Celsius above preindustrial levels (UNCCD, 2019; UNFCCC, 2021). More than one million species face extinction due to land degradation caused by human activities (IPBES, 2019), and about around a quarter of the world's human population are under threat of food insecurity (UNEP and $F A O, 2020)$. These crises are all interconnected and call for drastic changes in the way we manage and use land.

Natural terrestrial ecosystems absorb about $29 \%$ of total GHGs emissions (IPCC, 2019). Increasing carbon stocks in soils, on a global scale, has an estimated sequestration potential of 3.4-5 Gt C $\mathrm{yr}^{-1}$ (Smith et al 2020). In recognition of the role of soils in climate change mitigation and adaptation, initiatives such as the 4per1000 (Minasny et al., 2017) and FAO RECSOIL (Recarbonisation of global soils) have been launched. leveraging the momentum for SOC sequestration (FAO, 2019).

In the past, emission reductions in the AFOLU sector were largely unaccounted for due to concerns over permanence risks in the sector and difficulties in monitoring (Unger and Emmer, 2018).
This left voluntary carbon markets as the main avenue available to public and private actors interested in trading in land-based emission offsets (Larson et al., 2011). According to Ecosystem Marketplace ${ }^{1}$, interest in the AFOLU sector has been driven by an increasing awareness of nature-based solutions, scientific evidence supporting the improved tracking of $\mathrm{GHG}$ emission fluxes, and political support for SLM practices.

Africa has over 2.6 million $\mathrm{km}^{2}$ of cropland, with a large potential for soil carbon storage, ranging from 0.15 to $0.31 \mathrm{Pg} \mathrm{C} / \mathrm{yr}$. (Sommer and Bossio, 2014). Soil stewardship will play an important role in maintaining and increasing soil organic carbon. For example, in Tanzania it is estimated that up to $50 \%$ of the carbon in soils has been lost due to agricultural practices (Winowiecki et al., 2016a) Low levels of SOC stocks in croplands in sub-Saharan Africa indicate that there are opportunities for farmers to participate in payments for ecosystem services (PES) schemes based on soil carbon sequestration and storage (Zomer et al., 2017). For example, spatial assessments of SOC across sub-Saharan Africa could be used to prioritise and track interventions (Vågen et al., 2016; Winowiecki et al., 2016 b). Incentivising smallholder farmers to adopt agricultural practices that increase carbon storage in soils, such as no-till farming, cover crop planting, agroforestry, and rotational grazing, could support climate change mitigation and adaptation efforts and provide other co-benefits such as sustainable increases in agricultural productivity (Zomer et al., 2017). 


\subsection{Carbon markets and carbon credit certification}

Two types of carbon markets exist: regulatory compliance and voluntary markets. The compliance market is used by companies and governments that are legally required to account for their GHG emissions and includes emissions trading related to the Clean Development Mechanism established under the Kyoto Protocol. The voluntary carbon market is comprised by consumers, providers, and third-party verifiers who voluntarily trade carbon credits outside of the compliance market.

At present, there are several carbon verifying bodies that set and monitor standards and methods within the voluntary offset market. These include: Verra (https://verra.org), Plan Vivo (https://www.planvivo.org), Scientific Certification Systems Global (https:// www.scsglobalservices.com/), and Gold Standard (https://www.goldstandard.org).

Methodologies to measure mitigation interventions are generally based on frameworks provided by certification bodies. Although steps have been taken to increase the scope of offset projects, a mainstream provider or standardising body for soil-based offsets is still lacking (Keenor et al., 2021).

\subsection{Participation of farmers and communities in carbon projects}

Although there are no overarching and unified safeguard protocols for SOC projects, most carbon certification standards require projects to "do no harm" to the community and to uphold social and environmental standards. These include, among others, recognising and respecting customary and statutory tenure rights, protecting biodiversity, obtaining free, prior and informed consent, and ensuring full and effective participation (Ribot and Larson, 2012). Programmes that exclude indigenous and local communities from participating in the planning and implementation of conservation projects threaten livelihoods and the stability of local communities. For instance, there have been reports of evictions in connection with REDD+ programmes, notably among forestdependent communities in Kenya and Nepal (Mackenzie, 2012). However, despite efforts to comply with safeguards, carbon payment schemes continue to grapple with various barriers that hinder the effective participation of farmers and communities. These include high implementation costs, untrustworthy intermediaries, and unfavourable social and political environments (Pascual et al., 2014).

\subsection{The structure and objective of the paper}

Drawing on a literature review as well as interviews with land-based carbon offset project leads, in this paper, we: (i) characterise approaches to farmers' engagement practices at different stages of the project cycle; (ii) identify possible barriers to smallholder farmers participation and; (iii) propose solutions that improve smallholder outcomes in agency and decision power. 


\section{Materials and methods}

\subsection{Conceptual framework}

\author{
Participation is "a process through \\ which stakeholders influence and share \\ control over development initiatives \\ and the decision and resources which \\ affect them" (Luyet et al., 2012). \\ Stakeholder participation aims to \\ uphold the rights of farmer communities, \\ mitigate project risks, and gather \\ information to aid in project design and \\ implementation.
}

For this study we applied participation typologies inspired by Arnstein's "ladder of participation" (Arnstein, 1969) and Cornwall's dissection of participation in development practice (Cornwall, 2008) to analyse farmers' participation in the various stages of land-based carbon offset projects.

We analysed participatory approaches according to the level of engagement achieved. Figure 1 illustrates the different

\begin{abstract}
levels of engagement and the pathway from project participatory tools to smallholder outcomes. We characterise one-way participation that serves only to spread information to passive receivers as information sharing. The next level is consultation, where information is shared and feedback sought, and collaboration is classified as participation that not only seeks feedback from stakeholders in various forums (meetings, workshops, focus group discussions etc) but also addresses the feedback and allows stakeholders to know how their feedback was incorporated. Joint decision-making gives power to stakeholders and is commonly used with stakeholders who have knowledge and expertise, while empowerment (or transformative participation) transfers control from the project proponents to community stakeholders (UN-REDD Programme, 2011; Foti et al., 2008).
\end{abstract}

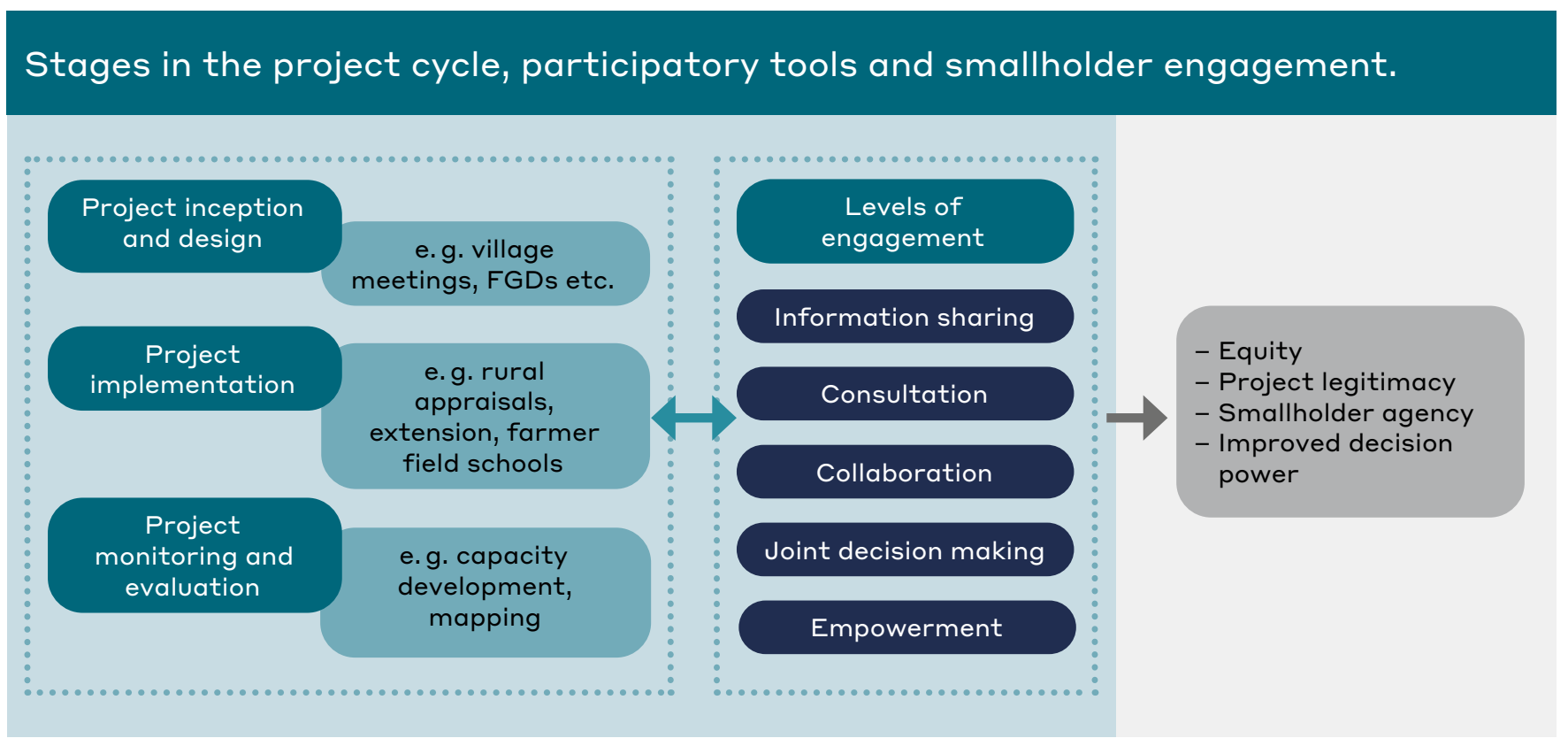

Figure 1: Conceptual framework representing the engagement of smallholders and communities through different phases of carbon-based projects and the intended outcomes of participation (e.g., smallholder equity, project legitimacy, smallholder agency and improved decision-making.) 


\subsection{Research design, and data collection and analysis}

This research has been guided by the following questions: 1) How are smallholder farmers engaged in land-based carbon offset projects?; 2) What limits or enables the effective and equal participation of smallholder farmers in such projects?; and 3) How do smallholder farmers benefit from these projects? Qualitative data, including a review of project documents and scientific literature, as well as key informant interviews helped us to explore these questions. We reviewed project design documents, and collated data on the participatory methodologies (including MRV approaches) used during the design and implementation of projects.

\subsubsection{Selection of land-based carbon offset projects}

We selected a total of ten projects registered in the voluntary carbon market that operate in a smallholder context (Table 1). The projects cover a range of carbon certification standards and different geographies, including Africa (8), Asia (1) and North America (1).

\subsubsection{Literature review}

We reviewed literature on MRV practices in carbon-based payment schemes in order to further characterise smallholder participation in these projects and identify barriers to participation in carbon payment schemes. Our initial scoped search focussed on papers that referred to PES schemes or carbon payment in the title abstracts or keywords. We then applied an inclusion criterion that included project/programme, smallholder participation, soil carbon and MRV to narrow down the initial results to seventeen papers. These papers were then screened by title and abstract to determine their relevance, resulting in eleven papers. We carried out an additional search to consider smallholder participation, MRV systems, and ecosystem valuation methods and metrics. The screened studies covered a wide range of themes (Table 2).

After removing duplicates, we subjected fifteen papers to a full text screening. This selection included non-peer reviewed studies (Porras and Blackmore, 2014; Shames et al., 2012). 
Table 1: List of carbon projects reviewed to examine smallholder participation and engagement

\begin{tabular}{|c|c|c|c|c|}
\hline Project name & Country & $\begin{array}{l}\text { Carbon } \\
\text { standard }\end{array}$ & Interventions & $\begin{array}{l}\text { SOC } \\
\text { methodology }\end{array}$ \\
\hline $\begin{array}{l}\text { Northern Kenya } \\
\text { Improved Grasslands } \\
\text { Project }\end{array}$ & Kenya & VERRA-CCB & Sustainable grazing & VCS SGMAFG \\
\hline $\begin{array}{l}\text { Trees for Global } \\
\text { Benefits }\end{array}$ & Uganda & Plan Vivo & $\begin{array}{l}\text { Afforestation/ } \\
\text { reforestation }\end{array}$ & Not accounted \\
\hline $\begin{array}{l}\text { Humbo Assisted } \\
\text { Regeneration project }\end{array}$ & Ethiopia & Gold Standard & $\begin{array}{l}\text { Forest \& landscape } \\
\text { restoration }\end{array}$ & Not accounted \\
\hline Scolel'te & Mexico & Plan Vivo & $\begin{array}{l}\text { Afforestation/ } \\
\text { reforestation }\end{array}$ & SHAMBA \\
\hline Mikoko Pamoja & Kenya & Plan Vivo & Mangrove conservation & Not accounted \\
\hline $\begin{array}{l}\text { Kenya Agricultural } \\
\text { Carbon Project (KACP) }\end{array}$ & Kenya & VERRA VM0017 & $\begin{array}{l}\text { Sustainable land } \\
\text { management }\end{array}$ & RothC \\
\hline Halo Verde Timor & East Timor & Plan Vivo & $\begin{array}{l}\text { Afforestation/ } \\
\text { reforestation }\end{array}$ & SHAMBA \\
\hline $\begin{array}{l}\text { Emiti Nibwo Bulora / } \\
\text { Trees Sustain Life }\end{array}$ & Tanzania & Plan Vivo & $\begin{array}{l}\text { Afforestation/ } \\
\text { reforestation }\end{array}$ & Not accounted \\
\hline $\begin{array}{l}\text { Livelihoods Mt Elgon } \\
\text { Project }\end{array}$ & Uganda & Gold Standard & $\begin{array}{l}\text { Dairy carbon value } \\
\text { creation }\end{array}$ & Not accounted \\
\hline $\begin{array}{l}\text { International Small } \\
\text { Group and Tree } \\
\text { Planting Program } \\
\text { (TIST) }\end{array}$ & $\begin{array}{l}\text { Kenya, } \\
\text { Tanzania, } \\
\text { India }\end{array}$ & VERRA-CCB & $\begin{array}{l}\text { Afforestation/ } \\
\text { reforestation }\end{array}$ & Not accounted \\
\hline
\end{tabular}


Table 2: Themes covered by the research studies included in the study
Theme
Research study

Sustainable land management practices

Nyberg et al., 2020; Dougill et al., 2012; Branca et al., 2011;

Tennigkeit et al., 2013

Rangeland management Lipper et al., 2010

Household decision-making on land use Dougill et al., 2012

Improved monitoring Wells et al., 2017; Fortmann et al., 2016

Non-monetary benefits/co-benefits

Somarriba et al., 2013; Nyberg et al., 2020; Lipper et al., 2010

Equity

Lee et al., 2015; Holmes et al., 2017; Howard et al., 2015;

Lasco et al., 2010

Monetary benefits

Milder et al., 2010

Ecosystem valuation methods

Naime et al., 2020

Metrics

Kearney et al., 2017; Tennigkeit et al., 2013

\subsubsection{Interview of key informants}

The key informant interviews served to develop an understanding of farmers' engagement across the lifecycle of various projects, with a particular emphasis on MRV activities. We interviewed experts and project leads who worked on/with the surveyed projects (Table 1) to better understand farmer engagement in land-based carbon offset projects and the challenges faced by projects when engaging with smallholders. Practices that facilitate farmer engagement, farmer agency, and decisionmaking power in schemes that promote SLM for soil carbon storage were also discussed.
Semi-structured interviews were conducted between 4-26 March 2021 by means of teleconferencing due to Covid-19 safety restrictions. During the interviews, we elicited insights on strategies used to engage smallholders and/or community members at different stages of the project lifecycle. We also sought to understand how projects involved smallholders and community groups in project monitoring systems and whether such efforts bolstered farmer agency and improved decisionmaking. 


\section{Results and discussion}

\subsection{Approaches to smallholder participation and engagement}

\subsubsection{Smallholders' participation in project design}

\begin{abstract}
A review of project design documents and interviews with key informants showed that participatory project design was common among all surveyed projects. Individual smallholders and communities were consulted through needs assessment (in the form of PRAs), meetings, discussions, interviews, and surveys. Plan Vivo-certified projects (60\% of surveyed projects) had a specific approach that engaged individual smallholders in planning by developing personal plans called 'Plan Vivos' (Table 3).
\end{abstract}

The consultation of local stakeholders with the aim of sensitising targeted communities was a common requirement across carbon credit certification bodies. Eighty percent of the projects surveyed featured a bottom-up approach to SLM that enabled communities to define indicators for social, economic, and environmental performance.

Specifically, projects certified by Plan Vivo, Gold Standards and the Climate, Community and Biodiversity (CCB) Standards followed these guidelines. High levels of participation, such as joint decision-making, were achieved by projects that took a bottom-up approach to project design. For example, the Humbo, Ethiopia Assisted Natural Regeneration Project, certified by Gold Standard, used participatory rural appraisals (PRAs) during baseline assessments to give the community a chance to comment on project design, express community needs, and provide feedback on potential risks (World Vision Ethiopia, 2018). PRAs were also utilised by the KACP and the Mikoko Pamoja projects to rank community priorities.

Thirty percent of the projects surveyed mentioned communication mechanisms that disseminated information to participating communities, including the use of village noticeboards, word of mouth, and newsletters during the project design and inception phases. For example, multiple meetings were held during the inception phase of the Trees Sustain Life project, which was implemented in the Kagera region of Tanzania and registered with Plan Vivo (Vi Agroforestry, 2010). These meetings not only served to communicate plans to the community but were also the basis for the inclusion of community needs into project design.

Interviews with project leads highlighted the participatory processes adopted and implemented across the assessed projects (Table 3 ). The KACP established strong field extension networks and involved government extension workers as well as community facilitators to implement project activities ( Vi Agroforestry, 2012). During its inception, the proponents sought to build awareness among farmers of the project's SLM interventions and to recruit farmer groups. The contracting process targeted farmer groups for training and offered advisory services in sustainable agricultural land management practices. The spatial targeting of carbon project sites was determined using PRA methods, and farm boundaries were mapped using GPS. In the only project to engage smallholders in delineation (Halo Verde 
Timor), mapping was conducted by either Vi Agroforestry zonal coordinators or local community facilitators ( $\mathrm{Vi}$ Agroforestry, 2012). The Trees for Global Benefits (TGB) project in Uganda ensured the full and effective participation of local communities by discussing project issues with a network of farmers, CBOs, and project coordinators. Farmer groups were contracted to ease both project administration and communication, but individual participation was maintained through individual agreements.

Table 3: List of participation techniques employed by the surveyed projects.

Techniques were collated from descriptions in annual reports and project design documents.

Project name

Northern Kenya Improved

Grasslands Project

Trees for Global Benefits (TGB)

\section{Deployed techniques for farmer participation}

Household survey, participatory landscape classification

Newsletters, webpage, notice board, interviews, conferences surveys, consultative meetings, rapid rural appraisals, workshops, Plan Vivos

Humbo Assisted Regeneration

Interviews, focus group discussions, consultative workshop, PRA

Project

Scolel'te

Newsletter, website, sensitisation meetings, Plan Vivos capacity building/training

Mikoko Pamoja

Consultation meetings, local spokespersons, PRA, Plan Vivos, participatory forest management plan

Kenya Agricultural Carbon

Project (KACP)

Halo Verde Timor
Sensitisation meetings, PRA, capacity building

Consultation meeting, social survey, facilitated farmer discussions, participatory mapping, Plan Vivos, project steering committee, farmer field days

Emiti Nibwo Bulora / Trees

Consultation meetings, sensitisation meeting, Plan Vivos

Sustain Life

Livelihoods Mt. Elgon Project Sensitisation meetings

International Small Group and

Newsletters, public seminars

Tree Planting Program (TIST) 
This study also found that community members were given a leading role in the production of their own land management plans (Plan Vivo Standards, 2013). These individualised plans were found in design documents of both the Scolel'te project in Mexico and the TGB initiative in Uganda. Landowners were engaged to draw up individual plans for their landholdings through visioning workshops. This approach facilitated the clear communication of the expected costs and benefits of participating in the project and empowered participants to make informed decisions (Cooperativa Ambio, 2019; Ecotrust, 2020). However, while farmers were given the opportunity to co-develop plans for their farms, the process was governed by technical specifications that had previously been determined at the programme level (Porras and Blackmore, 2014), placing limits on smallholders' participation in the design and inception of the project.

\subsubsection{Smallholders' participation in project monitoring systems}

Soil carbon pools were frequently excluded from carbon monitoring protocols due to the high costs involved in measuring and monitoring soil carbon stocks.

Thirty percent of the surveyed projects used verified methodologies to account for changes in soil carbon stocks (Table1). Among the methodologies used were the SHAMBA methodology, which was applied in the Scolel'te and Halo Verde Timor projects, and RothC (used in the KACP project). Smallholders' participation in the monitoring of carbon credits was encouraged in the KACP, Scolel'te, and TIST projects. Modelling, however, is often conducted offsite. The KACP project (Vi Agroforestry,
2012) used the RothC ${ }^{2}$ process model to determine baseline emissions using data collected from pre-inception surveys. To determine additionality, the KACP project used two approaches: permanent farm monitoring, where a representative sample of farm households is interviewed periodically by extension agents throughout the project's lifetime using a structured questionnaire, and; farmer group monitoring, in which data is collected from all of the participating farmers (Vi Agroforestry, 2012). In the case of the latter, farmers are trained to conduct and report an annual self-assessment and to report and manage potential data entry errors. However, these activity-based models are not coupled with soil sampling. The SHAMBA methodology is designed specifically for smallholder projects in the tropics and consists of the RothC model to account for soil and is optimised for use by non-specialists. In the Scolel'te project, community technicians selected from among the participating farmers were trained to carry out monitoring.

Similarly, the International Small Group \& Tree Planting Program (TIST) in Kenya (CCAFS, 2012;TIST, 2011), designed the project to engage farmers in self-monitoring and auditing, and in training other farmers to monitor project outcomes. Trained farmers, called Quantifiers, visited each small farmer group once per year, and gathered data on tree growth and age and transmitted it via the internet to the TIST website (https://www.tist.org/ i2/monmeas.php). Quantifiers received explicit training on TIST's standard operating procedures so that quantifications were performed in a standard and regular fashion (CCAFS, 2012). To independently check the 
accuracy and reliability of reported data or the procedures used to generate that information, TIST managers visited selected project areas and verified the reported quantities. They were also required to periodically audit Quantifiers, including an independent sampling of tree counts and circumference measurements. However, it is not clear if soil samples were also collected.

\subsubsection{Carbon payment modalities}

The review of project documents indicated that carbon payments are made in instalments to farmers, based on their performance. These payments are made on the basis of carbon sales agreements between projects and project participants. These agreements specify the carbon accreditation period (in line with the technical specifications) and a payment schedule. Projects generally retain a fraction of the carbon revenue in order to maintain a contingency fund. For example, the TGB project managed an accreditation period of ten years, with the first payments made in the inception year when seedlings were planted, and subsequent instalments in years one, three, five, seven, and ten. The project withheld $10 \%$ of the payments as a risk contingency fund in case farmers failed to meet their targets. The Scolel'te project also signed agreements for a ten-year accreditation period and staggered payments so that farmers received $90 \%$ of their carbon payments in years five and seven; the remainder was retained by the project as a risk buffer.
On the other hand, TIST signed sales agreements with farmers that established a price of USD 0.02 per tree/year, regardless of measured sequestration. They then paid farmers for actual carbon credits generated per household, with a typical payment of USD 904 per hectare for a woodlot (Carter, 2009). Vi Agroforestry distributed $60 \%$ of revenues to farmers based on the monitoring of activities and estimated carbon sequestered. The remainder was retained to pay for project management services and the remuneration of field extension agents (CCAFS, 2012). The timing of payments also varied throughout this project, with payments made to farmer groups as soon as the implementation of practices could be verified, simplifying the process by targeting groups rather than individuals (Shames et al., 2012).

In the Livelihoods Mt Elgon project in Kenya, the main benefit was increased farm productivity in dairy production, and communities were fully aware that carbon revenues did not represent the primary incentive for the project.

Interviews with project leads revealed that there was no guarantee that carbon revenues would be distributed to the farmers and that it was more likely they would be used to offset the financing of the project itself. The project leads emphasised the need for marketing strategies that would increase demand for and, ultimately, revenues from the sale of carbon credits. The distribution of carbon payments could be simplified by projects contracting groups of farmers rather than individual smallholders. Distributing cash to dozens or even hundreds of groups is nevertheless challenging. TIST adopted the 
innovative solution of paying farmers through M-PESA, a Kenyan mobile phone-based money transfer system that uses text messaging to allow farmers to claim payments at local banks.

In general, while carbon payments are low across most projects (Shames et al., 2012), there is hope that the contracts will be able to yield higher revenues in the future, following a rise in demand from non-regulated sectors and a $30 \%$ increase in prices for carbon credits from nature-based solutions in 2019 (Ecosystems Marketplace, 2020) as well as the potential inclusion of land use activities in the Paris Agreement's market mechanism.

\subsection{Barriers to the participation of farmers in soil carbon projects}

\subsubsection{Land tenure}

In our review of the literature on carbon payment projects, we found that land tenure issues were a key barrier to the implementation of soil carbon certification schemes as the clear distinction between landowners and land users is necessary to facilitate the compensation of participants (Lipper et al., 2010). Certification bodies such as Plan Vivo tackle issues of land tenure by ensuring that project beneficiaries secure a legally recognised land tenure of at least twenty years before enrolling in the project. However, securing access to land can be challenging for farmers operating in systems where tenure agreements may not exceed a specified length or where customary and legitimate claims to land are not officially documented.
Where smallholders lack formal land use rights, or where legal land rights exist but are not yet enforced, the demonstrable potential to produce mitigation benefits can aid farmers lobbying for land use rights. To establish carbon payments, projects resort to customary norms and practices, facilitated by local land organisations, to confer tenure rights and substantiate claims for payment (Dougill et al., 2012). Ultimately, community-based projects can act as a catalyst in attaining community land titles for communally owned lands and in the generation of community resource management plans. While operating on privately-held land can facilitate the identification of land rights, the experience of projects implemented on communal land suggests that under communal ownership, land use changes are best managed and compensated by local level institutions (Dougill et al., 2012). Their involvement can foster collective action, strengthen farmers' negotiation power, and reduce transaction costs (i.e., monitoring and general administrative costs are lower where smallholders can be aggregated into groups). For example, communitybased natural resource management can promote smallholder participation by enabling groups of smallholders to make better decisions. In their study of the TGB project, Dougill et al., (2012) suggested that strong institutional frameworks and clear communication of the costs and benefits of programmes are the main factors driving local participation. 
Our study also found that farmers who lack legal tenure rights run the risk of exclusion. However, this issue can be addressed by adjusting project activities to cater for these disadvantaged groups. For instance, in the TGB project, landless participants could obtain licences from the National Forest Authority to develop spaces in public land that granted them rights to the trees and all the products and services. These participants could also engage in income-generating activities such as tree nursery development in order to diversify their income sources. Social innovations such as community-led lease guidelines or intrahousehold agreements are additional instruments to ensure that vulnerable populations can access land and thus participate in such initiatives.

\subsubsection{Contracting}

We found that the role of contracts in driving engagement was often overlooked due to their inconsistent performance across communities with varying degrees of cohesion. While contracts have been found to be an effective tool to improve participation among cohesive indigenous communities by providing additional avenues to cashflows, this effect is yet to be seen among private landowners with inconsistent social bonds (Porras and Blackmore, 2014). Project proponents could show greater flexibility in the design of contracts in order to make participation attractive to farmers by tailoring key aspects such as their duration (farmers prefer longer contracts), the contract providers (farmers prefer local actors), payment schedules (e.g., monthly payments) and conservation activities (preference for low-cost interventions) (Fortmann et al., 2016).

\subsection{Enhancing farmers' role and agency in carbon payment projects}

\subsubsection{Non-monetary incentives for participation}

Interviews with project leads revealed that carbon offset revenues from land use activities were low. Non-carbon benefits, such as improved farm productivity, often represented the primary pay-off for farmers and their main motivation for participating in carbonbased payment projects (Nyberg et al., 2020;Tennigkeit et al., 2013). Carbon payment projects can deliver co-benefits at the farm level such as greater crop productivity through improved soil health, access to extension services, and the diversification of income sources through the establishment of tree nurseries (Branca et al., 2013). These are often key benefits for farmers and key drivers of smallholder participation. 
Innovative smallholder carbon projects can offer a range of benefits to encourage smallholder participation. Both the Livelihoods Mt. Elgon project and the TGB project offer non-carbon benefits in the form of financial advisory services and access to credit for participating farmers. By requiring and supporting farmer groups to open bank accounts, the projects enabled farmers to access credit by using their carbon payment contracts as collateral. Other non-carbon benefits included improvements in livelihoods. The KACP project expanded the scope of its activities to include livestock farming, while the Mikoko Pamoja project directed its earnings to investments that benefit the community such as the development of an ecotourism hub and improved fisheries management leading to increased food security.

\subsubsection{The role of local institutions and civil society organisations}

Our literature review also highlighted the role of local institutions in enhancing farmers' participation in land-based carbon payment schemes. Farmers' participation can be mediated by civil society organisations that are well established within communities. For example, the inclusion of non-governmental organisations in a PES scheme in Northern Tanzania was a key factor in facilitating negotiations and communicating the costs, benefits, and risks to upstream and downstream users of water resources targeted for improved management (Branca et al., 2011). In the case of a blue carbon scheme on the coast of Kenya, the Kenya Marine Fisheries Research Institute (KEMFRI) successfully secured the participation of the community by establishing community tenure over the mangrove and seagrass resources. Working with existing civil society organisations also enabled the project to reduce operating costs and helped to drive organisational improvements. Lipper et al., (2010) underscore the benefit of strong institutional frameworks for projects operating in areas with communal property rights and recommend that projects adopt communal contracts to reduce transaction costs. The Humbo Ethiopia Assisted Natural Regeneration Project credited the project's permanence and success in upscaling to its ability to hand over project management to local institutions, illustrating the importance of building on existing structures and institutions. Project leads also highlighted the importance of increasing collaboration between different community-based organisations operating in a given area, which can not only provide support networks for smallholders but also reduce the transaction costs across projects, for example by sharing knowledge, and pooling financial resources to acquire agricultural equipment and inputs. 


\section{Conclusions and Recommendations}

Soil organic carbon sequestration in smallholder farming systems can contribute to food and nutrition security, ecosystem restoration as well as climate change mitigation and adaptation. Land-based PES schemes can incentivise smallholder farmers to adopt sustainable soil management practices. However, methodologies for smallholder participation and safeguards are not harmonised and vary across carbon accounting standards.

The key findings from the literature review and key informant interviews show, on the one hand, that participation in land-based carbon payment projects is negatively affected by insecure land tenure and limited resource capacities among marginalised smallholders. On the other hand, farmers' participation can be mediated by civil society organisations that are well established within communities. These can facilitate clear communication between project proponents and farmers, increase farmers' bargaining power in negotiations, and reduce transaction costs. Nonetheless, efforts are required to strengthen farmers' capacities, and enhance their participation in MRV activities and the marketing of carbon credits. There is a real need for robust monitoring systems that engage farmers, while also capturing variabilities that exist across agroecological landscapes and farming systems. On-the-ground monitoring systems can be coupled with activitybased monitoring and Earth observation to provide accurate and low-cost SOC assessments, while also building capacity in monitoring as well as trust in the reporting system. Safeguarding principles can be upheld by empowering farmers in negotiations and contracting, strengthening land tenure and carbon rights, and generating non-carbon benefits for farmers.

With carbon payments relatively low across the projects surveyed, non-carbon co-benefits currently constitute a main incentive for smallholders' participation in land-based carbon payment schemes. These include improved farm productivity, reduced on-farm degradation, access to financial advisory services and credit, and investments in local infrastructure. Such co-benefits play a central role in carbon payment projects, as they can enhance the likelihood of permanence: a central issue related to the credibility of soil carbon credits. 


\section{References}

Branca, G., Lipper, L., McCarthy, N., Jolejole, M. C., 2013. Food security, climate change, and sustainable land management. A review. Agron. Sustain. Dev. https://doi.org/10.1007/s13593-013-0133-1

Branca, G., Lipper, L., Neves, B., Lopa, D., Mwanyoka, I., 2011. Payments for watershed services supporting sustainable agricultural development in Tanzania. J. Environ. Dev. 20, 278-302. https://doi.org/10.1177/1070496511415645

CCAFS, 2012. Case Study: The International Small Group Tree Planting Program (TIST) Kenya.

Cooperativa Ambio, 2019. Project Design Document Scolel'te 52.

Cornwall, A., 2008. Unpacking "Participation" Models, meanings and practices. Community Dev. J. 43, 269-283. https://doi.org/10.1093/cdj/bsn010

Dougill, A. J., Stringer, L. C., Leventon, U., Riddell, M., Rueff, H., Spracklen, D. V., Butt, E., 2012. Lessons from community-based payment for ecosystem service schemes: From forests to rangelands. Philos. Trans. R. Soc. B Biol. Sci. 367, 3178-3190. https://doi.org/10.1098/rstb.2011.0418

Ecotrust, 2020. Trees for Global Benefits.

Fortmann, L., Cordero-Salas, P., Sohngen, B., Roe, B., 2016. Incentive contracts for environmental services and their potential in REDD. Int. Rev. Environ. Resour. Econ. 9, 363-409. https://doi.org/10.1561/101.00000080

Foti, J., De Silva, L., McGray, H., Shaffer, L., Talbot, U., Werksman, J., 2008. Voice and choice : opening the door to environmental democracy. World Resources Institute.

Holmes, I., Kirby, K. R., Potvin, C., 2017. Agroforestry within REDD+: experiences of an indigenous Emberá community in Panama. Agrofor. Syst. 91, 1181-1197. https://doi.org/10.1007/s10457-016-0003-3

Howard, R. U., Tallontire, A., Stringer, L., Marchant, R., 2015. Unraveling the Notion of "Fair Carbon": Key Challenges for Standards Development. World Dev. 70, 343-356. https://doi.org/10.1016/j.worlddev.2015.02.008

IPBES, 2018. The IPBES assessment report on land degradation and restoration, in: Montanarella, L., Scholes, R., Brainich, A. (Eds.), Secretariat of the Intergovernmental Science-Policy Platform on Biodiversity and Ecosystem Services. p. 744.
IPBES, 2019. The global assessment report on BIODIVERSITY AND ECOSYSTEM SERVICES: SUMMARY FOR POLICYMAKERS. https://doi.org/10.1111/padr.12283

IPCC, 2019. Climate Change and Land: an IPCC special report, Climate Change and Land: an IPCC special report on climate change, desertification, land degradation, sustainable land management, food security, and greenhouse gas fluxes in terrestrial ecosystems.

Kearney, S. P., Coops, N. C., Chan, K. M. A., Fonte, S. U., Siles, P., Smukler, S. M., 2017. Predicting carbon benefits from climate-smart agriculture: Highresolution carbon mapping and uncertainty assessment in El Salvador. J. Environ. Manage. 202, 287-298.

https://doi.org/10.1016/j.jenvman.2017.07.039

Keenor, S. G., Rodrigues, A. F., Mao, L., Latawiec, A. E., Harwood, A. R., Reid, B. J., 2021. Capturing a soil carbon economy. R. Soc. Open Sci. https://doi.org/10.1098/rsos.202305

Larson, D. F., Dinar, A., Aapris Frisbie, J., 2011. Agriculture and the Clean Development Mechanism.

Lasco, R. D., Evangelista, R. S., Pulhin, F. B., 2010. Potential of Community-Based Forest Management to Mitigate Climate Change in the Philippines. Small-scale For. 9, 429-443. https://doi.org/10.1007/s11842-010-9132-0

Lee, J., Martin, A., Kristjanson, P., Wollenberg, E., 2015. Implications on equity in agricultural carbon market projects: a gendered analysis of access, decision making, and outcomes. Environ. Plan. A 47, 2080-2096. https://doi.org/10.1177/0308518×15595897

Lipper, L., Dutilly-Diane, C., McCarthy, N., 2010. Supplying carbon sequestration from West African rangelands: Opportunities and barriers. Rangel. Ecol. Manag. 63, 155-166. https://doi.org/10.2111/REM-D-09-00009.1

Luyet, V., Schlaepfer, R., Parlange, M.B., Buttler, A., 2012. A framework to implement Stakeholder participation in environmental projects. J. Environ. Manage. 111, 213-219. https://doi.org/10.1016/j.jenvman.2012.06.026

Mackenzie, C., 2012. REDD+ social safeguards and standards review. For. Carbon Mark. Communities Program. Arlington, VA. Available from http//www. fcmcglobal. org/documents/ Safeguards_Paper.pdf. 
Milder, J. C., Scherr, S. J., Bracer, C., 2010. Trends and future potential of payment for ecosystem services to alleviate rural poverty in developing countries. Ecol. Soc. 15, 6. https://doi.org/10.5751/ES-03098-150204

Minasny, B., Malone, B. P., McBratney, A. B., Angers, D. A., Arrouays, D., Chambers, A., Chaplot, V., Chen, Z.S., Cheng, K., Das, B.S., Field, D.J., Gimona, A., Hedley, C. B., Hong, S. Y., Mandal, B., Marchant, B. P., Martin, M., McConkey, B. G., Mulder, V. L., O'Rourke, S., Richer-de-Forges, A. C., Odeh, I., Padarian, U., Paustian, K., Pan, G., Poggio, L., Savin, I., Stolbovoy, V., Stockmann, U., Sulaeman, Y., Tsui, C. C., Vågen, T. G., van Wesemael, B., Winowiecki, L., 2017. Soil carbon 4 per mille. Geoderma.

https://doi.org/10.1016/j.geoderma.2017.01.002

Naime, U., Mora, F., Sánchez-Martínez, M., Arreola, F., Balvanera, P., 2020. Economic valuation of ecosystem services from secondary tropical forests: trade-offs and implications for policy making. For. Ecol. Manage. 473. https://doi.org/10.1016/j.foreco.2020.118294

Nyberg, Y., Musee, C., Wachiye, E., Jonsson, M., Wetterlind, J., Öborn, I., 2020. Effects of agroforestry and other sustainable practices in the Kenya Agricultural Carbon Project (KACP). Land 9, 1-22. https://doi.org/10.3390/land9100389

Pascual, U., Phelps, U., Garmendia, E., Brown, K., Corbera, E., Martin, A., Gomez-Baggethun, E., Muradian, R., 2014. Social equity matters in payments for ecosystem services. Bioscience. https://doi.org/10.1093/biosci/biu146

Plan Vivo Standards, 2013.

Porras, I., Blackmore, E., 2014. Innovations for equity and inclusion in smallholder payments for ecosystem services A workshop report. London.

Ribot, U., Larson, A. M., 2012. Reducing REDD risks: Affirmative policy on an uneven playing field. Int. J. Commons. https://doi.org/10.18352/ijc.322

Shames, S., Wollenberg, E., Buck, L. E., Kristjanson, P., Masiga, M., Biryahwaho, B., 2012. Institutional innovations in African smallholder carbon projects $8,1-27$.

Shankland, A., Hasenclever, L., 2011. Indigenous Peoples and the Regulation of REDD+ in Brazil: Beyond the War of the Worlds? IDS Bull. 42, 80-88.
Smith, P., Soussana, J. F., Angers, D., Schipper, L., Chenu, C. Rasse, D. P., Batjes, N. H., van Egmond, F., McNeill, S., Kuhnert, M., Arias-Navarro, C., Olesen, U. E., Chirinda, N., Fornara, D., Wollenberg, E., ÁlvaroFuentes, U., Sanz-Cobena, A., Klumpp, K., 2020. How to measure, report and verify soil carbon change to realize the potential of soil carbon sequestration for atmospheric greenhouse gas removal. Glob. Chang. Biol. https://doi.org/10.1111/gcb.14815

Somarriba, E., Cerda, R., Orozco, L., Cifuentes, M., Dávila, H., Espin, T., Mavisoy, H., Ávila, G., Alvarado, E., Poveda, V., Say, E., Deheuvels, O., 2013. Carbon stocks and cocoa yields in agroforestry systems of Central America. Agric. Ecosyst. Environ. 173, 46-57. https://doi.org/10.1016/j.agee.2013.04.013

Sommer, R., Bossio, D., 2014. Dynamics and climate change mitigation potential of soil organic carbon sequestration. J. Environ. Manage. 144. https://doi.org/10.1016/j.jenvman.2014.05.017

Tennigkeit, T., Solymosi, K., Seebaver, M., Lager, B., 2013. Carbon intensification and poverty reduction in Kenya: Lessons from the Kenya agricultural carbon project. F. Actions Sci. Rep. 7.

TIST, 2011. CCBA Project Description for TIST Program in Kenya CCB-002 for validation under The Climate, Community and Biodiversity Standard Second Edition.

Tubiello, F. N., Salvatore, M., Ferrara, A. F., House, U., Federici, S., Rossi, S., Biancalani, R., Condor Golec, R. D., Jacobs, H., Flammini, A., Prosperi, P., Cardenas-Galindo, P., Schmidhuber, J., Sanz Sanchez, M. J., Srivastava, N., Smith, P., 2015. The Contribution of Agriculture, Forestry and other Land Use activities to Global Warming, 1990-2012. Glob. Chang. Biol. https://doi.org/10.1111/gcb.12865

UN-REDD Programme, 2011. A Draft Framework for Sharing Approaches.

UNFCCC, 2021. Nationally determined contributions under the Paris Agreement: Synthesis report by the secretariat, Conference of the Parties serving as the meeting of the Parties to the Paris Agreement.

Unger, M. von, Emmer, I., 2018. Carbon market incentives to conserve, restore and enhance soil carbon. Silvestrum Nat. Conserv. 
Vågen, T.-G., Winowiecki, L. A., Tondoh, U. E., Desta, L. T., Gumbricht, T., 2016. Mapping of soil properties and land degradation risk in Africa using MODIS reflectance. Geoderma 263, 216-225.

Vågen, T.-G.; Winowiecki, L. A. Predicting the Spatial Distribution and Severity of Soil Erosion in the Global Tropics using Satellite Remote Sensing. Remote Sens. 2019, 11, 1800.

https://www.mdpi.com/2072-4292/11/15/1800

Vi Agroforestry, 2010. Emiti Nibwo Bulora "Trees sustain life" $1-42$.

VI Agroforestry, 2012. VCS Project Description Template KENYA AGRICULTURAL CARBON 1-79.

Wells, G., Fisher, J. A., Porras, I., Staddon, S., Ryan, C., 2017. Rethinking Monitoring in Smallholder Carbon Payments for Ecosystem Service Schemes: Devolve Monitoring, Understand Accuracy and Identify Co-benefits. Ecol. Econ.

https://doi.org/10.1016/j.ecolecon.2017.04.012

Winowiecki, L., Vågen, T.-G., Massawe, B., Jelinski, N. A., Lyamchai, C., Sayula, G., Msoka, E., 2016a.

Landscape-scale variability of soil health indicators: effects of cultivation on soil organic carbon in the Usambara Mountains of Tanzania. Nutr. Cycl. Agroecosystems 105. https://doi.org/10.1007/s10705-015-9750-1

Winowiecki, Leigh, Vågen, T.-G., Huising, J., 2016b. Effects of land cover on ecosystem services in Tanzania: A spatial assessment of soil organic carbon. Geoderma 263, 274-283.

https://doi.org/10.1016/j.geoderma.2015.03.010

World vision Ethiopia, 2018. HUMBO. CDM-AR-PDD-FORM Project design document form (afforestation or reforestation) Page 1 of 102 CDM-AR-PDD-FORM 02, 1-102.

Zomer, R. U., Bossio, D. A., Sommer, R., Verchot, L. V., 2017. Global Sequestration Potential of Increased Organic Carbon in Cropland Soils. Sci. Rep. https://doi.org/10.1038/s41598-017-15794-8 


\title{
TMG Research
}

\author{
TMG - Think Tank for Sustainability \\ TMG Research gGmbH \\ EUREF-Campus 6-9 \\ 10829 Berlin, GERMANY \\ Phone: +49309210740700 \\ Email: info@tmg-thinktank.com \\ Website: www.tmg-thinktank.com \\ DOI: https://doi.org/10.35435/2.2021.4
}

This publication was made possible with the financial support by the German Federal Ministry for Economic Cooperation and

Development (BMZ). 